\title{
THE KRUGER-AN OUTSIDER'S POINT OF VIEW
}

\author{
By The Secretary
}

The inspiration of most recent thought upon National Parks springs from the work done in 1933 at the London Conference for the Protection of African Fauna and Flora. The definition there adopted for the term "National Park" was, shortly, that it should mean an area placed under public control and set aside for the protection of wild animal life and wild vegetation, for the benefit and enjoyment of the general public. From this definition, already shortened, it is important to extract the object for which a National Park is formed and for which it is maintained. This object is the protection of wild life. It is not the enjoyment of the general public, for that is a different thing altogether, a result following the attainment of the object. There are other things which may also be mistaken for the object, such as the making of profit for Government by the attraction of tourists, the provision of a wild life laboratory for scientific research, the education of students in ecology or even the provision of playgrounds for the people. Some of these may be by-products of the success of the park, or factors affecting the method by which this success is assured, but they are meaningless unless the park itself is established as an area of safety for the indigenous fauna and flora of the country.

This re-statement of the problem of National Parks leads us to an appreciation of the situation which has arisen in the first of them in Africa, and perhaps the greatest of them all, the Kruger National Park. The object of this park is the preservation of what remains of the wild life of South Africa-clear and simple enough, but the factors affecting its attainment are far from simple.

The Kruger is in need of money. A considerable sum is of course necessary for mere maintenance but, besides this, large capital expenditure is now required under two headings, for the animals and for the visitors. For the animals the cry is "water". Of good grazing there is not a shortage, but animals must have drinking water within a comparatively short distance of their food. Where water supplies are more than about twelve miles apart, grazing remains unused and animals migrate westwards out of the park in search of water, many to return no more. Some boreholes have been sunk, but to provide the requisite number a widespread appeal for funds has been made recently by the Warden, Colonel Sandenbergh. 
'The needs of visitors are less simple but must be carefully considered, for visitors are the source from which is drawn the money to bear the brunt of maintenance expenses. The whole park is open to visitors from towards the end of May to the middle of October and from every administrative point of view it would be best if visitors could be spread evenly over this period. What actually happens? In 1949, during July, the children's holiday time, some twenty-four thousand people flocked to the park, each visitor staying an average of $\mathbf{3} \cdot \mathbf{3}$ days. This strained the accommodation almost beyond its limit and, as it meant that every day some three thousand people were in the park, tended to react unfavourably upon the animals. 'That number is certainly as many as the park can hold and keep its wildness. But in June and August the total numbers fell to about eight thousand; in September only five thousand two hundred came.

Why then has the park the popularity it deserves only during the children's holidays, and why do those who visit it stay usually for little more than three days? It is said that the camps are uncomfortable; certainly that at Skukuza is too large and has been nicknamed the "Barracks". Then undoubtedly the rule that visitors shall remain in their cars except when in camp detracts from the pleasure of the visit, or at least reduces the time that can enjoyably be spent. Imagine trying to keep children car-bound for more than three days. Lions provide the reason for this rule. They are perfectly safe if it is obeyed but, being no longer filled with fear of man, their reaction is unpredictable towards the visitor who leaves his car, particularly if he behaves foolishly. Still another factor affecting visitors is the state of the roads, which require repair and extension-a tarred road the length of the Park would bring the less frequented parts in the north within easier reach.

Let us turn now to some of the methods by which our object, the welfare of the animals, may be attained, remembering that a constant supply of money from visitors is essential.

A direct source of money could be obtained by the acquisition by the Park Authorities of trading rights within the park. At present, under the National Parks Act, the Parks Board is compelled to let out these rights to contract. Undoubtedly it would seem more profit would be obtained if the Board were allowed to do its own trading within the Park, though it must be remembered that any loss would likewise fall on the Board; but perhaps this is a negligible risk.

Many suggestions have been put forward to attract more 
visitors, especially American visitors, and to encourage them to stay longer in the park. These may be grouped under comforts and amusements, indoor intellectual facilities and outdoor facilities.

Undoubtedly more camps are needed and they should be much smaller than that at Skukuza. The question of what accommodation and amenities are required within a camp has been much discussed, ideas varying from the simplest standards to the most comfortable arrangements with even swimmingpools, tennis courts, and provision for the care of small children while their parents are in the park. On the other hand it is contended that the essence of the visit is a feeling of a return to nature which would be destroyed by any approach to the luxury hotel. Perhaps both the luxury seeker and the lover of the simple life should be catered for in different camps, and at a different price.

Turning from the body to the mind, many visitors feel the need for a library where they may read of the animals they have seen and learn to distinguish them. Along the same train of thought lie exhibitions of animals photographs and wild life cinema shows. Talks by a member of the Park staff are suggested and perhaps the same person might sometimes be available to answer visitor's questions about the animals. Finally can anything safely be done to permit of exceptions to the rule obliging visitors to remain in their cars except when in camp? Could walks be arranged for parties shepherded by a Park ranger?

Admittedly the best way to protect the animals would be to have a properly guarded game reserve without provision for tourists, but no plan can usefully be offered which ignores the unsurmountable reluctance of governments to provide funds without monetary return or political advantage. An unguarded game reserve is merely a paradise for poachers; for the true sportsman who obeys the law and even in part acts as a policeman will not enter there. So the money factor must be kept to the forefront.

Firstly then let the negligible risk of loss be accepted and the right to trade within the park be given go the National Parks Board. Next, the degree of bodily comfort required in the camps depends upon the mentality of the visitors. Few will be enthusiastic naturalists; the majority will be ordinary folk whose enjoyment will depend about equally upon their comfort and upon what they see of the animals. All will regard the animals as the reason for their visit; most, being on holiday, will want to leave their domestic cares behind them and will 
want their food provided; but few indeed will want luxury hotels, and the provision of these with their swimming-pools and tennis courts would be a speculative enterprise not to be undertaken. On the other hand for those who wish to do their own domestic work a very simple camp already exists at Oliphants River. More camps on the lines of this one may be required.

Our plan, which is intended to satisfy the average visitor, will include neither cinema shows of wild life nor museumsthese he can see in his own home town. He comes to see living animals and he wishes to be able to recognize them and to learn a little of their habits. That he may do this some books and photographs must be obtainable; though he will enjoy an impromptu talk with a Ranger he will not want any organized instruction-nor would it be at all easy to provide competent instructors.

Although it is not suggested that it is unnecessary to restrict visitors to their cars while outside the camps, it is felt that here lies the root cause of the shortness of their stay, the lack of freedom to wander ; and even if organized walks with a Ranger should be found possible, the feeling of restriction would remain.

It will be seen that no solution has been found to the problem of increasing the time that visitors will spend in the Park and that, unless important factors have been neglected in this appreciation, the most that can be hoped for is to increase the number of visitors who will make short stays during months other than July. That the acquisition of trading rights by the Parks Board and the improvement in camp conditions would increase revenue is undoubted, but it cannot be hoped that revenue will ever cover such capital expenses as boreholes for water, and roads. These can be paid for only by government grants, justified by the indirect revenue provided by such a world-famed asset as the Kruger National Park. 